\title{
The role of knowledge and power in climate change adaptation governance: a systematic literature review
}

\author{
Martinus J. Vink ${ }^{l}$, Art Dewulf ${ }^{1}$ and Catrien Termeer ${ }^{1}$
}

\begin{abstract}
The long-term character of climate change and the high costs of adaptation measures, in combination with their uncertain effects, turn climate adaptation governance into a torturous process. We systematically review the literature on climate adaptation governance to analyze the scholarly understanding of these complexities. Building on governance literature about long-term and complex policy problems, we develop a conceptual matrix based on the dimensions knowledge and power to systematically study the peer-reviewed literature on climate adaptation governance. We find that about a quarter of the reviewed journal articles do not address the knowledge or power dimension of the governance of climate change adaptation, about half of the articles discuss either the knowledge or the power dimension, and another quarter discuss both knowledge and power. The articles that do address both knowledge and power (1) conceptualize the governance of climate adaptation mainly as a complex system of regulatory frameworks and technical knowledge, (2) assume that regulatory systems can be easily adapted to new knowledge, (3) pay little attention to fluid or unorganized forms of power, e.g., negotiation, and knowledge, e.g., learning, and (4) largely neglect the interplay between the two. We argue that more research on this interplay is needed, and we discuss how puzzling and powering are a promising pair of concepts to study this.
\end{abstract}

Key Words: adaptive institutions; climate change; governance of climate adaptation; interactive framing; learning; literature on climate adaptation; models; negotiating; politics

\section{INTRODUCTION}

Although scientific attention to climate change has been steadily growing over the last decades, media attention and policy attention have been much more erratic (Boykoff 2012, Vink et al. 2013). The more recent rise in scientific attention to adaptation to climate change as a governance challenge that requires actions on the part of civil society, business, and particularly government has not led nation states to unconditionally implement climate adaptation policies (Repetto 2008, Biesbroek et al. 2010, Keskitalo 2010, Berrang-Ford et al. 2011, Ford and Berrang-Ford 2011, Wolf 2011). This seems at odds with a majority of climate change adaptation governance (CCAG) literature, which specifically stresses the need for state intervention (Biesbroek et al. 2013). Evidently, the growing body of scientific knowledge does not of itself lead to growing consistency in societal attention, political commitment, and state interventions.

As a quintessential long-term policy problem, the governance of adaptation to climate change relies on knowledge about long-term climate change impacts, and this knowledge is riddled with uncertainties. In addition, the long-term character of adaptation to climate change implies multiple policy cycles before impacts materialize and before the effects of adaptation measures can be evaluated. This makes decision making over adaptation to climate change prone to controversies about the knowledge base and leads to political conflict about interests and priorities (Lazarus 2008, Hovi et al. 2009, Lempert et al. 2009). Some have referred to climate change adaptation as a "wicked problem par excellence" (Rittel and Webber 1973,
Lazarus 2008, Davoudi et al. 2009, Jordan et al. 2010), which cannot be precisely formulated or solved, because of widely diverging problem formulations and vested interests. Others have stressed the complexities that come with monitoring and evaluating the progress of adapting to climate change (Ford et al. 2013). Accordingly, the governance of adaptation to climate change might be characterized by (1) inherent uncertainties, given the long-term character of this policy issue; (2) the involvement of many interdependent actors with their own ambitions, preferences, responsibilities, problem framings and resources; and (3) the lack of a well-organized policy domain for enhancing and monitoring climate adaptation in the policy agenda (Ford et al. 2013, Termeer et al. 2013).

In view of the characteristics making CCAG a quintessential long-term policy challenge, we review the broad literature on the governance of climate change adaptation to see whether and how the above-mentioned complexities are studied and theoretically understood. We present an exploratory systematic literature review of articles in international peerreviewed scientific journals on the governance of adaptation to climate change. Guided by literature outside the field of CCAG on long-term policy problems, the review is focused on how knowledge organization, power organization, and their interplay are addressed in this literature.

We start with theoretical considerations of the role of knowledge and power, both in organized and unorganized forms, in solving long-term wicked problems. After formulating the specific research questions for our review, we 
explain our methodological approach to selecting and categorizing the literature. We present a quantitative and qualitative analysis of the literature, categorized according to the conceptualization of knowledge and power in climate change adaptation governance. We discuss how the concepts of puzzling and powering, in combination with interactional framing, might be helpful in better understanding the understudied interplay of unorganized forms of knowledge and power in climate adaptation governance processes.

\section{THEORETICAL FRAMEWORK}

Although some impacts of anthropogenic climate change are already visible (Parmesan and Yohe 2003, Füssel 2009), most impacts are to be expected in the future (IPCC 2007a, Rockström et al. 2009). Even though current climate adaptation policies try to anticipate today's risks of natural disasters (IPCC 2012) or future climate impacts by making no-regret investments now (Fankhauser et al. 1999, Heltberg et al. 2009) or by mainstreaming adaptation goals in current policies (Smit and Wandel 2006, Swart and Raes 2007), CCAG goals and intentions generally aim decades ahead. Where policy cycles generally imply a four- to six-year time frame, the long time horizon of a changing climate makes policy results become real only multiple policy cycles ahead. This implies an extraordinary scope for policy makers, whose political success normally depends on policy impacts at the end of each policy cycle. In addition, this long-term perspective makes CCAG depend on intrinsically uncertain knowledge. Not only do climate models come with intrinsic uncertainty about the timing and severity of climate impacts, the future characteristics of society also are intrinsically unknowable. At the same time, although the future is unknown and unknowable, it will not crystallize in random forms (van Asselt 2010). Current policy decisions, resource mobilization, infrastructure decisions, and regulations may have serious consequences for the future. However, the role of these decisions and the context in which the current decisions will play out is intrinsically uncertain and may be valued differently by different people at different times.

This ambiguity in assessing future impacts of current policy decisions poses specific challenges to policy makers, challenges that have not only yielded a history of techniques and methods for creating plausible scenarios or models about the future (Wells 1902, de Jouvenel 1967, Thompson et al. 1992, Adler and Ziglio 1996, Ferri et al. 2006, Masini 2006, van Asselt et al. 2007, Klooster 2008, van Asselt 2010), but also have sparked a debate on the implications of uncertain knowledge about the future, especially in relation to ambiguous societal understanding. Scholars have empirically studied the limited role of uncertain knowledge in policy making for long-term issues (Dammers 2000, van der Steen 2009, Boezeman et al. 2010) and have theoretically addressed the wicked or unorganized character of policy problems with uncertain knowledge in combination with ambiguous societal problem definitions, goals, and values over time (Rittel and Webber 1973, Hisschemöller and Hoppe 1995, Lazarus 2008).

Not only is organizing the required knowledge for CCAG a daunting task, organizing the necessary power to get things done is challenging as well. Political success or failure, competing values, and conflicting interests all form part of what policy makers need to reckon with. In studies of quintessential long-term issues like macroeconomic reform and welfare state reform, this complexity in policy making is understood as an interplay of organizing knowledge about uncertain and ambiguous issues and organizing power amidst conflicting interests and goals (Hall 1993, Majone 1996, Visser and Hemerijck 1997, Culpepper 2002, Heclo 2010). When studying the role of knowledge and power organization, we need to consider both the organized and unorganized forms of knowledge and power. Not only is the role of agents in creating, changing, or disputing about knowledge and power important (Sabatier 1987, Sabatier 1988, Hall 1993, Heclo 2010), the role of organizational arrangements like models and institutions as (temporary) crystallizations of past learning and negotiation processes also is important (Dyson 1980, Scott 1987, Mahoney and Thelen 2010). These distinctions yield four categories that will guide our systematic review of the CCAG literature.

\section{Organized knowledge}

In view of an uncertain future, policy making may rely on models or scenarios to draw plausible pictures of how the future might look (van Asselt 2010). These forms of knowledge can be considered crystallizations of complex processes of knowledge development (de Jouvenel 1967, Masini 2006, Klooster 2008). In fields like public health these processes are often structured by using statistical methods referred to as Monte Carlo simulations (Thompson et al. 1992), or by using expert-based consensual approaches like the Delphi method (Adler and Ziglio 1996, Ferri et al. 2006). Once a certain amount of consensus has been reached among experts, knowledge will be formalized or crystallized in written or modeled form. As long as consensus holds, these organized forms of knowledge can be considered rather static and represent building blocks for policy making (van Asselt 2010). In the context of climate adaptation, the role of climate impact models in governing climate adaptation is often stressed as important for understanding the need for adaptation (Moss et al. 2010). Generally, this understanding relies on the climate scenarios in combination with socioeconomic scenarios presented in the Intergovernmental Panel on Climate Change (IPCC) reports (IPCC $b$ 2007).

\section{Unorganized knowledge}

Before knowledge crystallizes in models, scenarios, or technologies, experts and stakeholders will puzzle over what is actually at stake, or they may work toward agreement on a 
certain model of future reality. This knowledge in the making may be manifested in unorganized forms like learning, sharing knowledge, making sense, framing, or deliberating over the nature of the problem (Hall 1993, Schön and Rein 1994, Culpepper 2002, Heclo 2010). Although agreement is still to be found, agents interactively work toward agreement or build upon earlier forms of agreement (Dewulf et al. 2009). Once agreement is reached and formalized in models, these formalizations may be questioned again or may be changed after new knowledge comes to the fore. Hence, organized forms of knowledge are essentially temporal and may be altered by unorganized forms of knowledge like learning or deliberation among users of the models or experts who formalized the models out of earlier unorganized forms of knowledge.

\section{Organized power}

In view of changing future circumstances, CCAG has to achieve societal goals, often guided by unorganized forms of knowledge. Therefore governance needs power to get things done (Hall 1993, Culpepper 2002, Heclo 2010). A rather explicit form of power in governance may be the law, or other institutions that, once politically agreed upon, arrange society according to certain goals or procedures. Formal organizations, climate acts, official agreements, regulations, and state officials represent organized forms of power in governing society with the goal of climate adaptation (Dovers and Hezri 2010). These organized forms of power are materializations of previously negotiated outcomes regarding societal goals, values, and means, but they may change again once societal goals are renegotiated or specific agents strive for change and reach a new equilibrium (Dyson 1980, Scott 1987, Mahoney and Thelen 2010).

\section{Unorganized power}

Not all power is explicitly organized. During the process in which power gets organized in the form of regulations or institutions, power manifests itself in unorganized forms like negotiations or power plays between parties or coalitions that strive for conflicting goals interests or values (Sabatier 1987, Majone 1996, Heclo 2010). Agents negotiate over who gets what or which issue is more important than other issues. In addition, agents may strive for support or may build coalitions to gain power in a power play to get things formalized. This power play may build upon existing power organizations like institutions, official positions, or regulations, but may also challenge those power structures. New power structures may appear after the power play has stabilized, as new agreed-upon goals are formalized in new institutions or regulations (Sabatier 1987, 1988, Hall 1993, Heclo 2010).

\section{Research questions}

The question arises: How does the scientific literature on climate change adaptation governance make sense of these organized and unorganized forms of knowledge and power and their combinations? This brings us to our research questions: (1) To what extent are the organized and unorganized forms of knowledge and power and their combinations discussed in the CCAG literature? (2) How are organized and unorganized forms of knowledge and power and their combinations conceptualized in CCAG literature?

\section{THE METHODOLOGICAL APPROACH}

To answer the two research questions, we conducted a systematic exploratory study of the peer-reviewed climate adaptation governance literature. In line with the climate adaptation literature review by Berrang-Ford et al. (2011) and the general consideration of systematic literature reviews by Fischer, Tobi, and Ronteltap (2011), our systematic approach does not aim to cover all literature available, but because of its systematic approach, it provides a proxy or indication of what approaches to knowledge and power exist in CCAG literature. Therefore we make use of both quantitative and qualitative literature analysis, giving insight into the relative amount of literature available on the various approaches and the theoretical conceptualization of knowledge and power in these approaches.

\section{Categories for analyzing knowledge and power in climate change adaptation governance literature}

Starting from the general knowledge and power dichotomy, we defined two dimensions on which to review the literature. We defined a matrix in which the y axis represents the dimension of knowledge in CCAG, and the $\mathrm{x}$ axis represents the power dimension in CCAG (Fig. 1). We subsequently subdivided the dimensions of knowledge and power into organized and unorganized knowledge and power. Because of the possibility that climate adaptation governance literature discusses only knowledge aspects or only power aspects of the governance process, we added these categories to our matrix. We consider it ontologically impossible that power or knowledge play no role at all in actual CCAG processes, but it is possible that these dimensions are not discussed in particular publications.

\section{Literature selection and analysis}

The combination of the three categories on each axis (unmentioned, unorganized, organized) results in nine cells for allocating literature. For the selection of literature, we searched the Scopus scientific database (www.scopus.com), accessed December 1, 2012, for peer-reviewed articles on CCAG. We developed search queries with keywords and synonyms for each category on the $\mathrm{x}$ and $\mathrm{y}$ axes, based on the literature discussed above. We applied an iterative approach in developing search queries to be sure not to include irrelevant literature or exclude crucial literature. Each cell in Figure 1 represents a subselection of CCAG literature, based on a combination of literature selections with keywords that fit the categories on the $\mathrm{x}$ and $\mathrm{y}$ axes. For a list of search queries with keywords, refer to Appendix 1. 
Fig. 1. Analysis matrix based on conceptualizations of knowledge and power. CCAG = climate change adaptation governance.

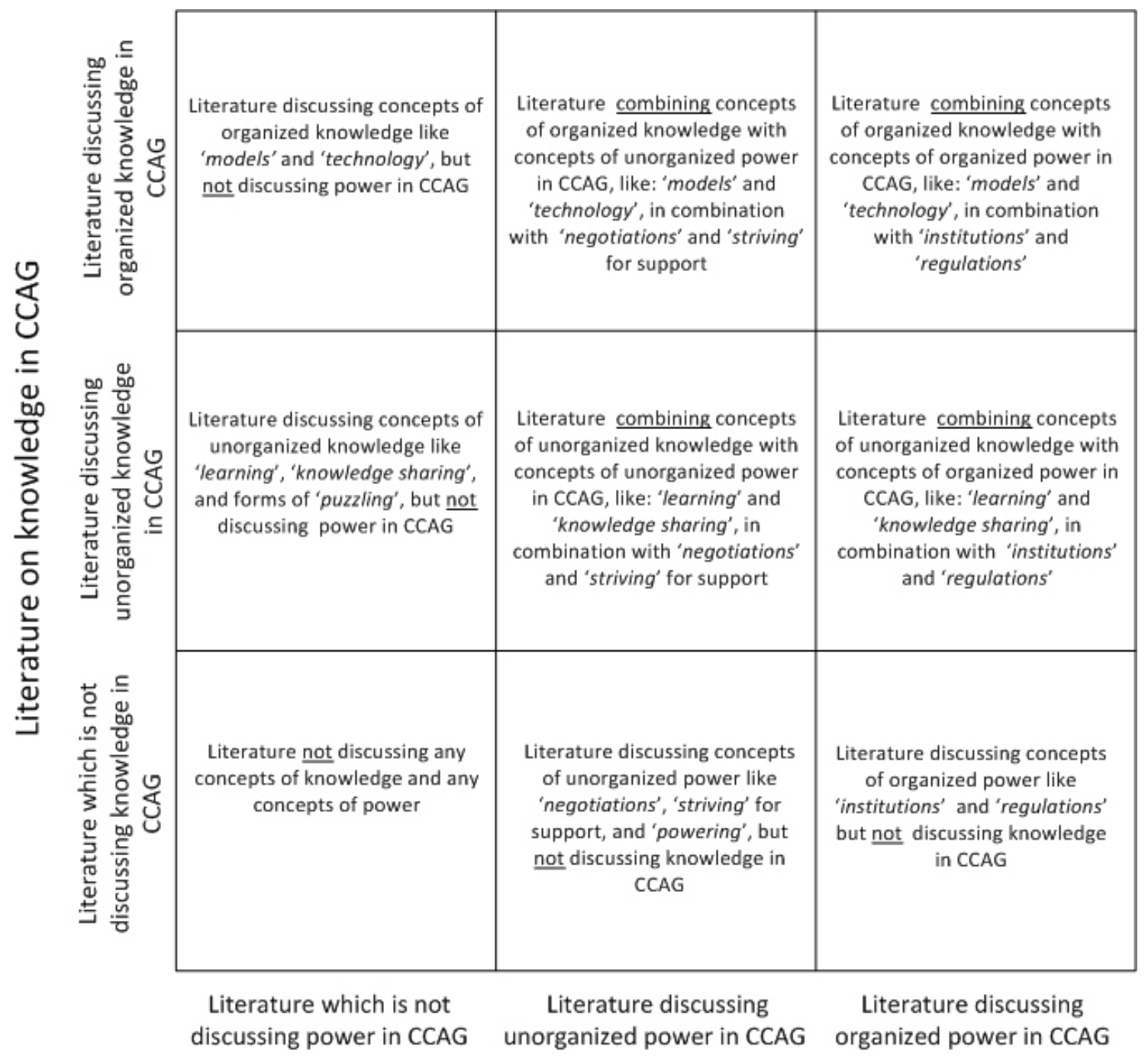

\section{Literature on power in CCAG}

After selecting the literature based on our knowledge and power categories, we quantitatively analyzed the distribution over the cells. We focused on the number of articles, year of publication, and the number of citations. Based on these quantitative characteristics, we drew conclusions on the relative amount of articles per category or cell, whether the articles were relatively recent or not, and whether the articles were cited relatively well or not.

Because our specific focus was on the approaches in literature that discuss the combination of knowledge and power, we analyzed qualitatively how the different selections of CCAG literature conceptualized the 4 combinations of unorganized and organized knowledge and unorganized and organized power. Because we aimed to provide a proxy or indication of the approaches in the literature, we reviewed the first 10 most cited articles of the literature selections that appeared relevant and did not add false positives to our selection criteria, e.g., we avoided power as in power plant. For structuring this qualitative analysis, we used the following questions:

1. Are the categories of knowledge and power being studied theoretically or empirically?

2. At what governance scale are the categories conceptualized in CCAG? 
3. How are knowledge, power, and the interplay of both conceptualized in CCAG?

The answers to those questions are listed per reviewed article in Tables A2.1 through A2.4 in Appendix 2. The tables enabled us to draw conclusions about the general conceptualizations of the combinations of knowledge and power, the governance scale at which most conceptualizations are focused, and to what extent the conceptualizations have led to coherent theoretical approaches to the knowledge-power interplay in CCAG.

\section{Methodological limitations}

The systematic approach of our review aims to yield a comprehensive analysis of the approaches in CCAG literature to knowledge and power. However, there are some limitations to be considered in systematic literature reviews. Although selecting English-language peer-reviewed articles in Scopus enhances the scientific quality and soundness of the reviewed approaches, there might be nonscientific, semiscientific, or non-English literature that represents insights that we currently have missed. In addition, our focus on the Scopus scientific database might limit the completeness of our search because other databases like Web of Science might have yielded additional literature (c.f. Biesbroek et al. 2013, Petticrew and Roberts 2008). However, the aim of our review is not to provide a full overview of the existing literature, but to be a proxy for the existing approaches in literature (c.f. Berrang-Ford et al. 2011), which are well represented in the Scopus database.

\section{QUANTITATIVE ANALYSES OF SELECTED LITERATURE}

The quantitative results are presented in Figure 2. The number in each cell represents the number of articles that appeared in the literature selection. The figures in bold represent the articles that include a combination of knowledge and power conceptualizations, which we therefore consider of special importance for qualitative in-depth reviewing.

\section{Quantitative analysis of literature on knowledge and power in climate change adaptation governance literature}

Looking at the total number of articles for each of the categories on the $\mathrm{x}$ and $\mathrm{y}$ axes in Figure 2, important differences can be noted. Of the 1132 articles accessed on 3 December 2012, more than half did not address knowledge (608), and more than half did not address power (684) in relation to CCAG. Although smaller, the selection of literature discussing organized knowledge, like models and techniques (438), or organized power, like institutions and regulation (436), is still relatively large. Compared to these larger selections of literature, literature discussing unorganized forms of knowledge like learning (181) or unorganized forms of power like negotiation (70) is only sparsely represented in our total selection of CCAG articles.
Fig. 2. Quantitative analyses of climate change adaptation governance (CCAG) literature.

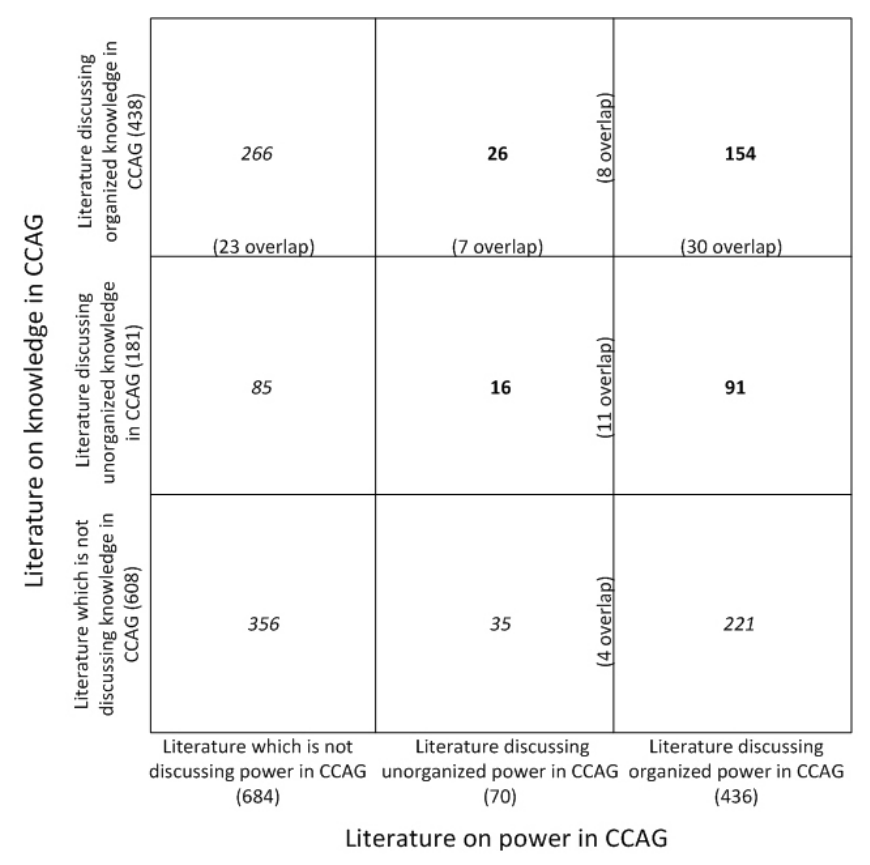

These differences are striking because we selected the literature for unorganized forms of knowledge and unorganized forms of power on the basis of a relatively large number of synonyms. However, these unorganized forms of knowledge and power still appear to be underrepresented in the total number of selected articles. In particular, the number of articles addressing the unorganized power element, where CCAG is approached as a product of negotiations over values and interests, appears to be limited (70).

\section{Quantitative analysis of literature on either knowledge or power in climate change adapation governance literature}

In line with the general variety in literature addressing knowledge or power in CCAG, we see a relatively large variety in the number of articles specifically focusing on either knowledge, without mentioning any form of power, or vice versa. Literature specifically focusing on unorganized power without mentioning any form of knowledge, e.g., CCAG as negotiating, is relatively underrepresented (35; see Fig. 2 for these numbers). The difference, compared to literature specifically addressing unorganized knowledge, e.g., CCAG as learning, which is still underrepresented but is more than double the amount (85) of the literature addressing unorganized power (35), is striking. Literature focusing on organized power without mentioning knowledge, e.g., CCAG as only institutions and regulations, is overrepresented (221), 
as is literature focusing on organized knowledge without mentioning any form of power (266), and literature that does not mention any form of knowledge or power (356). Apparently CCAG is mostly represented as either a matter of models and technologies or as a matter of institutions and regulations, or as not any form of knowledge or power.

\section{Quantitative analysis of literature combining knowledge and power in climate change adaptation governance literature}

Literature on the combination of knowledge and power reveals an even larger variety. The articles combining unorganized power and unorganized knowledge, e.g., CCAG as a combination of negotiating and learning, is only sparsely represented (16; see Fig. 2 for these numbers). A closer look reveals that the articles are relatively recent (all were after 2007, of which half were published in 2012), and were relatively infrequently cited compared to the other selections. Only one article was cited more than 5 times, and the mostcited article was cited 22 times (Scopus 2012). The same goes for the literature on unorganized power in combination with organized knowledge, e.g., CCAG as a combination of negotiating with models and techniques. This selection only had 26 articles, which are very recent, all after 2009 and half in 2012, and are not often cited yet; only 3 were cited more than 5 times, with the most-cited article cited 12 times (Scopus 2012). For all subselections, a computed $\mathrm{H}$-factor is presented in Appendix 1.

Focusing on the combination of unorganized knowledge with organized power, e.g., CCAG as a combination of learning with institutions, shows a different picture. There are 91 articles (Fig. 2) that are still rather recent, all after 2001 and half after 2011, but they are cited much more often; 29 articles are cited more than 5 times, of which the most-cited article is cited 272 times (Scopus 2012). The combination of organized knowledge with organized power, e.g., CCAG as a combination of models with institutions, yields the largest number of articles (154, see Fig. 2), which are the oldest, all after 1996, half after 2010, and most cited: 45 are cited more than 5 times, of which the most-cited article is cited 272 times (Scopus 2012). For all subselections, a computed H-factor is presented in Appendix 1.

The matrix also shows the overlap between the different literature selections. A number of papers fulfill more than one of our queries and are included in more than one selection, for example, addressing a combination of learning, negotiation, and institutions in CCAG. This overlap appears to be relatively small for the organized knowledge in combination with organized power literature selection. However, especially in relation to the few articles discussing unorganized power and unorganized knowledge in CCAG, the overlap consists of more than half the articles (Fig. 2). Apparently only a very small number of articles discusses only the combination of unorganized forms of knowledge and unorganized forms of power in CCAG.

\section{QUALITATIVE ANALYSES OF SELECTED LITERATURE}

Organized knowledge and organized power: the system assessment approach

Most articles in the organized knowledge and organized power selection (Table A2.1, Appendix 2) discuss national-level case studies. Some articles discuss forms of organized knowledge and organized power as central in CCAG (Mills 2005, Tompkins and Adger 2005, Challinor et al. 2007). In all articles selected, CCAG is pictured as a rather static system, in which, for example, institutions or regulations and models and techniques play an important role (Easterling 1996, Sanders and Phillipson 2003, Allman et al. 2004, Mills 2005, Tompkins and Adger 2005, Belliveau et al. 2006, Challinor et al. 2007, Tyler et al. 2007, Biesbroek et al. 2010, Ford et al. 2010). Only a few articles discuss how these organized forms of knowledge and power may interact, for example by the influence institutions may have on techniques (Tompkins and Adger 2005) or vice versa (Sanders and Phillipson 2003). Almost all articles conceptualize the two dimensions separately and assess how they independently influence a governance system's vulnerability or sensitivity to a changing climate. The type of governance systems discussed vary and include agriculture and livestock (Easterling 1996, Belliveau et al. 2006, Challinor et al. 2007, Tyler et al. 2007), insurance and societal damage (Sanders and Phillipson 2003, Mills 2005), health governance (Ford et al. 2010), and more general governance of public goods (Allman et al. 2004, Tompkins and Adger 2005, Biesbroek et al. 2010).

In general, we may conclude that this subselection of literature addressing knowledge and power in CCAG represents a rather homogeneous group of articles in their approach to CCAG, which is well balanced in terms of empirical research versus more theoretical research. Because these articles assess rather static elements in governance systems in view of a changing climate, their approach may be described as a system assessment approach (Fig. 3). In this approach, organized knowledge and power are often considered independent parameters and accordingly their interplay is not elaborated.

\section{Unorganized knowledge and organized power: the adaptive capacity approach}

Most articles in the unorganized knowledge and organized power selection (Table A2.2, Appendix 2) discuss nationallevel case studies or local case studies dealing with national governance (Shackley and Deanwood 2002, Tompkins 2005, Nelson et al. 2008, Tompkins et al. 2008, Dougill et al. 2010). A majority of articles discusses forms of unorganized knowledge and organized power as central in CCAG (Tompkins 2005, Nelson et al. 2008, Pelling et al. 2008, Tompkins et al. 2008, Pahl-Wostl 2009, Dougill et al. 2010, 
Fig. 3. Overview of the qualitative literature analyses. $\mathrm{CCAG}=$ climate change adaptation governance .

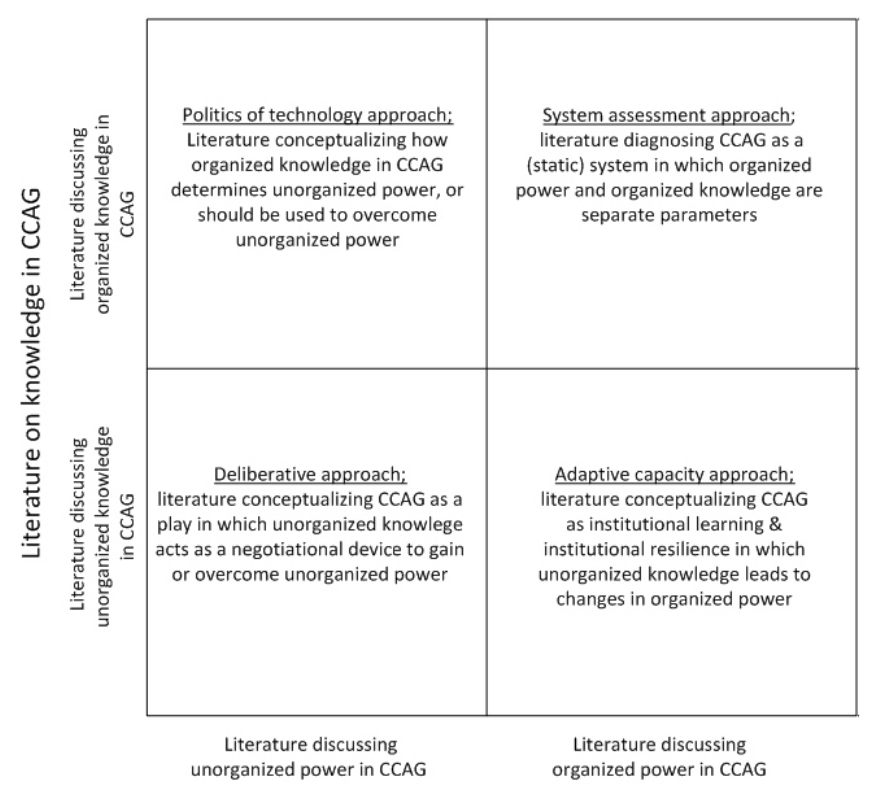

Literature on power in CCAG

Dovers and Hezri 2010). However, unlike the static system assessment approach discussed above, most articles discuss institutions and regulations as the context for a process of change through learning or sharing of knowledge. This process is conceptualized as institutional learning (Shackley and Deanwood 2002, Pelling et al. 2008, Tompkins et al. 2008, Pahl-Wostl 2009, Dougill et al. 2010, Dovers and Hezri 2010), which may lead to adaptive capacity (Tompkins and Adger 2005, Nelson et al. 2008, Gupta et al. 2010) or to institutional resilience (Tompkins 2005). Case studies address similar issues as those in the system assessment approach cell (Tompkins 2005, Nelson et al. 2008, Tompkins et al. 2008), but the majority have a more general approach to governance, which is not tied to a specific policy domain (Shackley and Deanwood 2002, Tompkins and Adger 2005, Pelling et al. 2008, Pahl-Wostl 2009, Dougill et al. 2010, Dovers and Hezri 2010, Gupta et al. 2010).

In general we can say that the literature that appeared in our selection is well balanced between empirical and theoretical research, and shows a rather consistent conceptualization of unorganized knowledge and organized power in CCAG in the form of a process of institutional learning leading to adaptive capacity or resilient systems. Therefore we could describe the approach to knowledge and power in this subselection as the adaptive capacity approach (Fig. 3).

\section{Organized knowledge and unorganized power: the politics of technology approach}

Most articles in the organized knowledge and unorganized power selection (Table A2.3, Appendix 2) discuss nationallevel case studies. Both the organized knowledge and unorganized power dimensions are mentioned as important in CCAG, sometimes even as central aspects of CCAG. However, both dimensions are referred to in a variety of ways, depending on the theoretical definition and normative standpoint of choice. Often articles appear to conceptualize the combination of organized knowledge and unorganized power as the politics of technology. Case descriptions are presented about how models determine technologies, and how these influence negotiation dynamics among government and stakeholders in CCAG (Carey et al. 2012). Mahony and Hulme (2012) further this idea by conceptualizing the power that comes with knowledge structures. The authors introduce a regional climate modeling system as a new way of knowing that goes beyond the hegemonic IPCC way of knowing. Therefore the authors claim that this new knowledge structure enables less powerful regions with little representation in the knowledge hegemony of the IPCC to make better use of climate models. This is where the authors link the role of organized knowledge and its implied power dynamics with better possibilities for learning.

In line with the role of organized knowledge in power dynamics, Underdal (2010) discusses different governance models that make use of different knowledge and power contraction or fragmentation, each model functioning best in specific conditions. Feldman (2012) discusses the problematic relation among models, technologies, and implementation that results from inefficient boundary work, which depends on power relations. In line with this boundary work, Roncoli et al. (2009) discuss the importance of modeling tools in combination with negotiation platforms, but conceptualize them separately. The interplay emerges where the authors describe how modeling tools give handles for negotiation, and how uncertainty in the modeling tool creates possible inconsistencies in framing what is at stake. This is where Roncoli et al. (2009) link up with the unorganized side of knowledge in CCAG. Roncoli et al. (2009) take a normative stance in saying that framings should be toward the Integrated Water Resource Management goals. McGee and Taplin (2009) address the role of technology as a discourse in international negotiations. With the introduction of discourse, they go beyond the role of technology itself in negotiations and introduce a less organized form of knowledge, shared meaning.

We can conclude that the conceptualization of both organized knowledge and unorganized power in CCAG is not common in CCAG literature, is not uniform, and is rather recent. Probably the best way to summarize the variety of conceptualizations of organized knowledge and unorganized 
power is the politics of technology approach (Fig. 3), in which technologies and models have an influence on and are strategically employed in negotiations at all levels of concern.

\section{Unorganized knowledge and unorganized power: the deliberative approach}

Most articles in the unorganized knowledge and unorganized power selection (Table A2.4, Appendix 2) discuss either national or international-level case studies. Both unorganized knowledge and unorganized power are mentioned as important in CCAG. Sometimes they are even mentioned as central aspects in CCAG. However, both dimensions are referred to in various forms, depending on the theoretical definition chosen. Some articles take a rather normative stance on the role of multistakeholder management and knowledge sharing to change or overcome existing power relations (Rojas et al. 2009, Roncoli et al. 2009, Manuel-Navarrete 2010, Feldman 2012).

In a multilateral context, Brown et al. (2007) mention the relation between the ideational development of climate change as a security issue and the effects this might have on international negotiations over supporting climate adaptation measures in Africa. In the same way Mahony and Hulme (2012) discuss how deliberation over organized knowledge like climate models may influence the applicability of those models in the global South, empowering countries who previously did not have a stake in the IPCC's way of knowing. Apparently, the interplay between forms of unorganized knowledge and unorganized power is applicable to international relations studies. At the national level, Vink et al. (2013) take up the interplay by describing the role of climate models in the development of frames in the processes of making Dutch water policy. The authors discuss the possible consequences of this framing for certain powering strategies. One article in our selection explicitly discusses learning and changing paradigms in relation to political negotiations. Via the concept of triple loop learning, Herrfahrdt-Pähle and PahlWostl (2012) link learning with changing values and institutions. In an abstract sense, this learning is related to sustained change in the characteristics of political negotiations over long-term issues like CCAG.

In general, we may conclude that the literature in our selection addressing unorganized knowledge and unorganized power in CCAG is rather recent and does not play a central role in the rest of the literature, as the relatively few citations to this subselection indicate. Depending on the theoretical framework, there appears to exist a wide variety of conceptualizations linking ideas, frames, or learning with power relations or negotiations. Some authors (Rojas et al. 2009, Roncoli et al. 2009, Manuel-Navarrete 2010, Feldman 2012) add a normative stance toward power relations in CCAG, yielding more critical approaches to the role of ideas in power relations. The few articles addressing international relations in CCAG show a more coherent conceptualization of the interplay of unorganized knowledge (ideas and frames) and unorganized power (international negotiations). Altogether, this rather recent literature, presenting a variety of approaches, could be summarized as a deliberative approach to CCAG (Fig. 3).

\section{DISCUSSION}

\section{Climate change adaptation governance as systems or as interplaying processes?}

The majority of articles addressing knowledge and power in CCAG do so using a system assessment approach in which organized knowledge and organized power are separate parameters. This body of literature shows a rather homogeneous conceptualization of governance and covers all governance levels of concern. In the same way, the literature discussing CCAG as an adaptive capacity challenge shows rather homogeneous conceptualizations. However, the politics of technology approach and the deliberative approach to knowledge and power in CCAG are sparsely represented in CCAG literature and show little consistency in their conceptualizations, compared to the other two approaches. Hence, in spite of what Heclo and others have shown in their fields of research (Sabatier 1988, Bennett and Howlett 1992, Schön and Rein 1994, Majone 1996, Culpepper 2002, Heclo 2010), a large part of the CCAG literature conceptualizes longterm policy making predominantly as a matter of "getting the system right," instead of understanding the interplaying processes of organizing knowledge and organizing support within those systems over time. Heclo (2010) and others (Visser and Hemerijck 1997; Culpepper, 2002, and Hoppe 2010 and 2011) have lebeled these interplaying processes as processes of puzzling and powering.

\section{Knowledge-power interplay}

The dynamic interplay between knowledge and power seems especially poorly represented in our selection of CCAG literature. In the system assessment approach, both knowledge and power are conceptualized as relatively static features of the CCAG system. Knowledge and power as interplaying processes remain largely unmentioned in the majority of the CCAG literature we reviewed. The adaptive capacity approach clearly shows the most consistent attention to a knowledgepower interplay. In this approach, the interplay is mostly related to institutional learning, where learning agents are key to institutional change. However, negotiations over societal values, interests, and goals underpinning the institutions often are not mentioned in this interplay.

Because knowledge and power are not coherently conceptualized in what we call the politics of technology approach, the knowledge-power interplay remains rather ambiguously understood here as well. Some authors consider technology and power as separate but conflicting (Underdal 
2010). Other authors describe how technology and models may become "handles" in negotiation (Roncoli et al. 2009), and some conceptualize the interplay as "discourse" (McGee and Taplin 2009). These conceptualizations of the knowledgepower interplay are furthered in what we defined as the deliberative approach, but they remain rather broadly defined in deliberation via knowledge networks (Feldman 2012), processes of framing (Vink et al. 2013), reframing (Mahony and Hulme 2012), and triple-loop learning (Herrfahrdt-Pähle and Pahl-Wostl 2012).

\section{Climate change adaptation governance as interplaying processes of puzzling and powering through interactive framing}

Considering the underrepresented approaches to CCAG as a process, and the ambiguously defined knowledge and power interplay, we see opportunities to further a process-based approach to CCAG by using conceptualizations in line with puzzling and powering (Heclo 2010). Although we understand that very general concepts like puzzling and powering pose limits to their analytical strength (Bennett and Howlett 1992, Hall 1993, Heclo 2010), we believe that the concept of interactive framing might be a promising analytical tool to make this interplay graspable. Schön and Rein (1994) address the knowledge and power interplay in form of frames. Framing is a process in which facts and values merge in the form of problem-setting story lines or metaphors. Explicitly or implicitly, these story lines link causal accounts of what is to particular proposals for action, implying a normative leap from what is to what ought to be.

The interplay of knowledge and power might be understood more precisely by describing the combination of learning and negotiating in the form of frame interactions. In the ambiguous context of climate change adaptation, agents make sense of what is and what ought to be by socially interacting through sharing, merging, or contrasting frames (Dewult et al. 2009 and 2013). In the same way, the role of technologies as handles in negotiations might become graspable by indicating the frames that are employed interactively in making sense of these technologies in governance processes. Whether from a normative stance or not, in this way CCAG might be described and understood as a process of interaction in which agents, strategically or not, frame future reality on the spot and interactively create shared meaning for rallying support.

\section{CONCLUSION}

Our first research question asked to what extent knowledge and power are being discussed in CCAG literature. The relatively large number of articles not discussing any form of knowledge or power, or knowledge in combination with power, is striking. In addition we can conclude that knowledge and power in the form of models, technologies, institutions, and regulations are most extensively discussed and cited as organized elements of knowledge and power in a CCAG system. In more recent literature, the concept of learning or adapting has been added to this system approach, which yielded a second relatively large body of literature, which is cited relatively often. Unorganized forms of knowledge and power, like learning in combination with negotiating, are relatively recent, and are little discussed or cited in CCAG literature. Hence, CCAG is mostly being discussed as a static system of models, technology, institutions, and regulation.

For our second research question, we asked how knowledge, power, and their interplay are discussed in the CCAG literature. Articles discussing organized forms of knowledge and power, like models and institutions, show relatively coherent conceptualizations in the form of governance systems, which the literature generally aims to assess in view of a changing climate. We therefore classified this approach to organized knowledge and power as the system assessment approach. Articles approaching unorganized knowledge, like learning, in relation to organized forms of power, like institutions, show relatively coherent conceptualizations in the form of adaptive capacity, institutional learning, and institutional resilience. We therefore classified this approach as the adaptive capacity approach.

The selection of literature approaching CCAG in terms of organized knowledge and unorganized power, for example, using models in combination with negotiating, shows limited coherence in conceptualization. Some authors provide interesting conceptualizations of the problematic character of knowledge hegemonies in power relations, but do not have a large influence on other CCAG scholars yet. We classified this approach as the politics of technology approach because most articles address the implicit power play that comes with knowledge structures. In the same way, our selection of literature that approaches CCAG as unorganized knowledge and unorganized power, for example, learning in combination with negotiating, shows limited coherence in its conceptualizations. Authors describe promising conceptualizations, such as triple loop-learning, boundary work, discourse, and framing, but they appear to be pioneers in the field of CCAG literature. Because most articles address the implicit power play that comes with the use of language, learning, or framing, we consider these subselections best described as the deliberative approach.

In addition to the variety of conceptualizations of knowledge and power, the interplay of knowledge and power in CCAG remains ambiguously understood. In line with Heclo (2010) and others, we therefore propose a theoretical lens of puzzling and powering for better understanding of the dynamic processes of organizing knowledge and power in CCAG. Together with that, we consider the theory of interactive framing a promising tool in making the interplay between puzzling and powering graspable, possibly helping to understand the puzzling and powering that might explain the 
empirical complications of climate adaptation governance interventions.

Responses to this article can be read online at: http://www.ecologyandsociety.org/issues/responses. php/5897

\section{Acknowledgments:}

We would like to thank Robbert Biesbroek and Hilde Tobi for their dedicated advice on the methodology of conducting systematic literature review research. In addition we would like to thank the Dutch Knowledge for Climate Programme for making this research available.

\section{LITERATURE CITED}

Adler, M., and E. Ziglio, editors. 1996. Gazing into the oracle: the Delphi Method and its application to social policy and public health. Jessica Kingsley, London, UK.

Allman, L., P. Fleming, and A. Wallace. 2004. The progress of English and Welsh local authorities in addressing climate change. Local Environment 9:271-283. http://dx.doi. org/10.1080/1354983042000219379

Belliveau, S., B. Smit, and B. Bradshaw. 2006. Multiple exposures and dynamic vulnerability: evidence from the grape industry in the Okanagan Valley, Canada. Global Environmental Change 16:364-378. http://dx.doi.org/10.1016/ j.gloenvcha.2006.03.003

Bennett, C. J., and M. Howlett. 1992. The lessons of learning: reconciling theories of policy learning and policy change. Policy Sciences 25(3):275-294. http://dx.doi.org/10.1007/ $\underline{\mathrm{BF} 00138786}$

Berrang-Ford, L., J. D. Ford, and J. Paterson. 2011. Are we adapting to climate change? Global Environmental Change 21:25-33.

Biesbroek, G. R., J. E. Klostermann, C. J. Termeer, and P. Kabat. 2013. On the nature of barriers to climate change adaptation. Regional Environmental Change 13(5):1119-1129.

Biesbroek, G. R., R. J. Swart, T. R. Carter, C. Cowan, T. Henrichs, H. Mela, M. D. Morecroft, and D. Rey. 2010. Europe adapts to climate change: comparing national adaptation strategies. Global Environmental Change 20:440-450. http:// dx.doi.org/10.1016/j.gloenvcha.2010.03.005

Boezeman, D., P. Leroy, R. Maas, and S. Kruitwagen. 2010. The (limited) political influence of ecological economics: a case study on Dutch environmental policies. Ecological Economics 69:1756-1764. http://dx.doi.org/10.1016/j. ecolecon.2010.04.013
Boykoff, M. 2012. Media coverage of climate change/global warming. Center for Science and Technology Policy Research, Boulder, Colorado, USA. [online] URL: http:// sciencepolicy.colorado.edu/media_coverage/

Brown, O., A. Hammill, and R. McLeman. 2007. Climate change as the 'new' security threat: implications for Africa. International Affairs 83:1141-1154. http://dx.doi.org/10.1111/ j.1468-2346.2007.00678.x

Carey, M., A. French, and E. O'Brien. 2012. Unintended effects of technology on climate change adaptation: an historical analysis of water conflicts below Andean glaciers. Journal of Historical Geography 38:181-191. http://dx.doi. org/10.1016/j.jhg.2011.12.002

Challinor, A., T. Wheeler, C. Garforth, P. Craufurd, and A. Kassam. 2007. Assessing the vulnerability of food crop systems in Africa to climate change. Climatic Change 83:381-399. http://dx.doi.org/10.1007/s10584-007-9249-0

Culpepper, P. D. 2002. Powering, puzzling, and 'pacting': the informational logic of negotiated reforms. Journal of European Public Policy, 9:774-790. http://dx.doi. org/10.1080/13501760210162357

Dammers, E. 2000. Leren van de toekomst: over de rol van scenario's bij strategische beleidsvorming. Proefschrift Universiteit Leiden. Eburon, Delft, Netherlands.

Davoudi, S., J. Crawford, and A. Mehmood. 2009. Planning for climate change: strategies for mitigation and adaptation for spatial planners. Earthscan/James and James, London, UK.

de Jouvenel, B. 1967. The art of conjecture. Basic Books, New York, New York, USA.

Dewulf, A., B. Gray, L. Putnam, R. Lewicki, N. Aarts, R. Bouwen, and C. Van Woerkum. 2009. Disentangling approaches to framing in conflict and negotiation research: a meta-paradigmatic perspective. Human Relations 62:155-193. http://dx.doi.org/10.1177/0018726708100356

Dewulf, A. 2013. Contrasting frames in policy debates on climate change adaptation. Wiley Interdisciplinary Reviews: Climate Change 4(4):321-330. DOI: 10.1002/wcc.227 http:// dx.doi.org/10.1002/wcc. 227

Dougill, A. J., E. D. G. Fraser, and M. S. Reed. 2010. Anticipating vulnerability to climate change in dryland pastoral systems: using dynamic systems models for the Kalahari. Ecology and Society 15(2): 17. [online] URL: http:// www.ecologyandsociety.org/vol15/iss2/art17/

Dovers, S. R., and A. A. Hezri. 2010. Institutions and policy processes: the means to the ends of adaptation. Wiley Interdisciplinary Reviews: Climate Change 1(2):212-231. http://dx.doi.org/10.1002/wcc.29 
Dyson, K. H. F. 1980. The state tradition in Western Europe: a study of an idea and institution. Oxford University Press, New York, New York, USA.

Easterling, W. E. 1996. Adapting North American agriculture to climate change in review. Agricultural and Forest Meteorology 80:1-53. http://dx.doi.org/10.1016/0168-1923 (95)02315-1

Fankhauser, S., J. B. Smith, and R. S. Tol. 1999. Weathering climate change: some simple rules to guide adaptation decisions. Ecological Economics 30:67-78. http://dx.doi. org/10.1016/S0921-8009(98)00117-7

Feldman, D. L. 2012. The future of environmental networks: governance and civil society in a global context. Futures 44:787-796. http://dx.doi.org/10.1016/j.futures.2012.07.007

Ferri, C. P., M. Prince, C. Brayne, H. Brodaty, L. Fratiglioni, M. Ganguli, K. Hall, K. Hasegawa, H. Hendrie, and Y. Huang. 2006. Global prevalence of dementia: a Delphi consensus study. The Lancet 366:2112-2117. http://dx.doi.org/10.1016/ S0140-6736(05)67889-0

Fischer, A. R. H., H. Tobi, and A. Ronteltap, 2011. When natural met social: a review of collaboration between the natural and social sciences. Interdisciplinary Science Reviews 36(4):341-358. http://dx.doi.org/10.1179/030801811X13160755918688

Ford, J. D., and L. Berrang-Ford, editors. 2011. Climate change adaptation in developed nations: from theory to practice. Advances in Global Change Research 42. Springer Science+ Business Media, New York, New York, USA. http:// dx.doi.org/10.1007/978-94-007-0567-8 1

Ford, J. D., L. Berrang-Ford, M. King, and C. Furgal. 2010. Vulnerability of Aboriginal health systems in Canada to climate change. Global Environmental Change 20:668-680. http://dx.doi.org/10.1016/j.gloenvcha.2010.05.003

Ford, J. D., L. Berrang-Ford, A. Lesnikowski, M. Barrera, and S. J. Heymann. 2013. How to track adaptation to climate change: a typology of approaches for national-level application. Ecology and Society 18(3): 40. http://dx.doi. org/10.5751/ES-05732-180340

Füssel, H.-M. 2009. An updated assessment of the risks from climate change based on research published since the IPCC Fourth Assessment Report. Climatic Change 97:469-482. http://dx.doi.org/10.1007/s10584-009-9648-5

Gupta, J., C. Termeer, J. Klostermann, S. Meijerink, M. van den Brink, P. Jong, S. Nooteboom, and E. Bergsma. 2010. The Adaptive Capacity Wheel: a method to assess the inherent characteristics of institutions to enable the adaptive capacity of society. Environmental Science and Policy 13:459-471. http://dx.doi.org/10.1016/j.envsci.2010.05.006
Hall, P. A. 1993. Policy paradigms, social learning, and the state: the case of economic policymaking in Britain. Comparative Politics 25:275-296. http://dx.doi.org/10.2307/422246

Heclo, H. 2010. Modern social politics in Britain and Sweden: from relief to income maintenance. ECPR Press, Colchester, UK.

Heltberg, R., P. B. Siegel, and S. L. Jorgensen. 2009. Addressing human vulnerability to climate change: toward a 'no-regrets' approach. Global Environmental Change 19:89-99. http://dx.doi.org/10.1016/j.gloenvcha.2008.11.003

Herrfahrdt-Pähle, E., and C. Pahl-Wostl. 2012. Continuity and change in social-ecological systems: the role of institutional resilience. Ecology and Society 17(2): 8. http://dx.doi. org/10.5751/ES-04565-170208

Hisschemöller, M., and R. Hoppe. 1995. Coping with intractable controversies: the case for problem structuring in policy design and analysis. Knowledge and Policy 8:40-60. http://dx.doi.org/10.1007/BF02832229

Hoppe, R. 2010. Lost in translation? A boundary work perspective on making climate change governable. Pages 109-130 in P. Driessen, P. Leroy, and W. van Viersen, editors. From climate change to social change: perspectives on science-policy interactions. International Books, Utrecht, Netherlands.

Hoppe, R. 2011. The governance of problems: puzzling, powering, and participation. Policy Press, Bristol, UK.

Hovi, J., D. F. Sprinz, and A. Underdal. 2009. Implementing long-term climate policy: time inconsistency, domestic politics, international anarchy. Global Environmental Politics 9:20-39. http://dx.doi.org/10.1162/glep.2009.9.3.20

Intergovernmental Panel on Climate Change (IPCC). $2007 a$. Climate change 2007: the physical science basis. S. Solomon, D. Qin, M. Manning, Z. Chen, M. Marquis, K. B. Averyt, M. Tignor, and H. L. Miller, editors. Contribution of Working Group I to the Fourth Assessment Report of the Intergovernmental Panel on Climate Change. Cambridge University Press, Cambridge, UK, and New York, New York, USA.

Intergovernmental Panel on Climate Change (IPCC). $2007 b$. Climate Change 2007: synthesis report. Core Writing Team, R. K. Pachauri, and A. Reisinger, editors. Contribution of Working Groups I, II and III to the Fourth Assessment Report of the Intergovernmental Panel on Climate Change, IPCC, Geneva, Switzerland.

Intergovernmental Panel on Climate Change (IPCC). 2012. Managing the risks of extreme events and disasters to advance climate change adaptation. C. B. Field, V. Barros, T. F. Stocker, D. Qin, D. J. Dokken, K. L. Ebi, M. D. Mastrandrea, K. J. Mach, G.-K. Plattner, S. K. Allen, M. Tignor, and P. M. 
Midgley, editors. Special report of the Intergovernmental Panel on Climate Change. Cambridge University Press, Cambridge, UK. http://dx.doi.org/10.1017/CBO9781139177245

Jordan, A., D. Huitema, H. van Asselt, T. Rayner, and F. Berkhout, editors. 2010. Climate change policy in the European Union: confronting the dilemmas of mitigation and adaptation? Cambridge University Press, Cambridge, UK. http://dx.doi.org/10.1017/CBO9781139042772

Keskitalo, E. C. H. 2010. Developing adaptation policy and practice in Europe: multi-level governance of climate change. Springer, New York, New York, USA. http://dx.doi. org/10.1007/978-90-481-9325-7

Klooster, S. A. van't. 2008. Toekomstverkenning; ambities en de praktijk; een etnografische studie van de productie van toekomstkennis bij het Ruimtelijk Planbureau $(r p b)$. Eburon, Delft, Netherlands.

Lazarus, R. J. 2008. Super wicked problems and climate change: restraining the present to liberate the future. Cornell Law Review 94:1153-1233.

Lempert, R., J. Scheffran, and D. F. Sprinz. 2009. Methods for long-term environmental policy challenges. Global Environmental Politics 9:106-133. http://dx.doi.org/10.1162/ glep.2009.9.3.106

Mahoney, J., and K. Thelen. 2010. Explaining institutional change. Cambridge University Press, Cambridge, UK. http:// dx.doi.org/10.1017/CBO9780511806414

Mahony, M., and M. Hulme. 2012. Model migrations: mobility and boundary crossings in regional climate prediction. Transactions of the Institute of British Geographers 37:197-211. http://dx.doi.org/10.1111/ j.1475-5661.2011.00473.x

Majone, G. 1996. Public policy and administration: ideas, interests and institutions. Oxford University Press, Oxford, UK. http://dx.doi.org/10.1093/0198294719.003.0026

Manuel-Navarrete, D. 2010. Power, realism, and the ideal of human emancipation in a climate of change. Wiley Interdisciplinary Reviews: Climate Change 1:781-785. http:// dx.doi.org/10.1002/wcc. 87

Masini, E. 2006. Rethinking futures studies. Futures 38:1158-1168. http://dx.doi.org/10.1016/j.futures.2006.02.004

McGee, J., and R. Taplin. 2009. The role of the Asia Pacific Partnership in discursive contestation of the international climate regime. International Environmental Agreements: Politics, Law and Economics 9:213-238. http://dx.doi. org/10.1007/s10784-009-9101-2

Mills, E. 2005. Insurance in a climate of change. Science 309:1040-1044. http://dx.doi.org/10.1126/science.1112121
Moss, R. H., J. A. Edmonds, K. A. Hibbard, M. R. Manning, S. K. Rose, D. P. van Vuuren, T. R. Carter, S. Emori, M. Kainuma, T. Kram, G. A. Meehl, J. F. B. Mitchell, N. Nakicenovic, K. Riahi, S. J. Smith, R. J. Stouffer, A. M. Thomson, J. P. Weyant, and T. J. Wilbanks. 2010. The next generation of scenarios for climate change research and assessment. Nature 463:747-756. http://dx.doi.org/10.1038/ $\underline{\text { nature } 08823}$

Nelson, R., M. Howden, and M. S. Smith. 2008. Using adaptive governance to rethink the way science supports Australian drought policy. Environmental Science and Policy 11:588-601. http://dx.doi.org/10.1016/j.envsci.2008.06.005

Pahl-Wostl, C. 2009. A conceptual framework for analysing adaptive capacity and multi-level learning processes in resource governance regimes. Global Environmental Change 19:354-365. http://dx.doi.org/10.1016/j.gloenvcha.2009.06.001

Parmesan, C., and G. Yohe. 2003. A globally coherent fingerprint of climate change impacts across natural systems. Nature 421:37-42. http://dx.doi.org/10.1038/nature01286

Pelling, M., C. High, J. Dearing, and D. Smith. 2008. Shadow spaces for social learning: a relational understanding of adaptive capacity to climate change within organisations. Environment and Planning A 40:867-884. http://dx.doi. org/10.1068/a39148

Petticrew, M., and H. Roberts. 2008. Systematic reviews in the social sciences: a practical guide. Blackwell, Malden, Massachusetts, USA.

Repetto, R. C. 2008. The climate crisis and the adaptation myth. Working paper number 13. Yale School of Forestry and Environmental Studies, New Haven, Connecticut, USA. [online] URL: http://www.climateneeds.umd.edu/pdf/ ClimateCrisisAdaptationMyth.pdf

Rittel, H. W. J., and M. M. Webber. 1973. Dilemmas in a general theory of planning. Policy Sciences 4:155-169. http:// dx.doi.org/10.1007/BF01405730

Rockström, J., W. Steffen, K. Noone, Å. Persson, F. S. Chapin, E. F. Lambin, T. M. Lenton, M. Scheffer, C. Folke, H. J. Schellnhuber, B. Nykvist, C.A. de Wit, T. Hughes, S. van der Leeuw, H. Rodhe, S. Sorlin, P. K. Snyder, R. Costanza, U. Svedin, M. Falkenmark, L. Karlberg, R. W. Corell, V. J. Fabry, J. Hansen, B. Walker, D. Liverman, K. Richardson, P. Crutzen, and Brian Foley. 2009. A safe operating space for humanity. Nature 461:472-475. http://dx.doi.org/10.1038/461472a

Rojas, A., L. Magzul, G. P. Marchildon, and B. Reyes. 2009. The Oldman River Dam conflict: adaptation and institutional learning. Prairie Forum 34:235-260.

Roncoli, C., P. Kirshen, D. Etkin, M. Sanon, L. Somé, Y. Dembélé, B. J. Sanfo, J. Zoungrana, and G. Hoogenboom. 2009. From management to negotiation: technical and 
institutional innovations for integrated water resource management in the Upper Comoé River Basin, Burkina Faso. Environmental Management 44:695-711. http://dx.doi. org/10.1007/s00267-009-9349-X

Sabatier, P. A. 1987. Knowledge, policy-oriented learning, and policy change: an advocacy coalition framework. Science Communication 8:649-692. http://dx.doi.org/10.1177/0164025987008004005

Sabatier, P. A. 1988. An advocacy coalition framework of policy change and the role of policy-oriented learning therein. Policy Sciences 21:129-168. http://dx.doi.org/10.1007/ $\underline{\mathrm{BF} 00136406}$

Sanders, C. H., and M. C. Phillipson. 2003. UK adaptation strategy and technical measures: the impacts of climate change on buildings. Building Research and Information 31:210-221. http://dx.doi.org/10.1080/0961321032000097638

Schön, D. A., and M. Rein. 1994. Frame reflection: toward the resolution of intractable policy controversies. Basic Books, New York, New York, USA.

Scott, W. R. 1987. The adolescence of institutional theory. Administrative Science Quarterly 32:493-511. http://dx.doi. org/10.2307/2392880

Shackley, S., and R. Deanwood. 2002. Stakeholder perceptions of climate change impacts at the regional scale: implications for the effectiveness of regional and local responses. Journal of Environmental Planning and Management 45:381-402. http://dx.doi.org/10.1080/09640560220133414

Smit, B., and J. Wandel. 2006. Adaptation, adaptive capacity and vulnerability. Global Environmental Change 16:282-292. http://dx.doi.org/10.1016/j.gloenvcha.2006.03.008

Swart, R., and F. Raes. 2007. Making integration of adaptation and mitigation work: mainstreaming into sustainable development policies? Climate Policy 7:288-303.

Termeer, C., A. Dewulf, and G. Breeman. 2013. Governance of wicked climate adaptation problems. Pages 27-39 in J. Knieling and W. L. Filho, editors. Climate change governance. Springer, New York, New York, USA. http://dx. doi.org/10.1007/978-3-642-29831-8_3

Thompson, K. M., D. E. Burmaster, and E. A. Crouch. 1992. Monte Carlo techniques for quantitative uncertainty analysis in public health risk assessments. Risk Analysis 12:53-63. http://dx.doi.org/10.1111/j.1539-6924.1992.tb01307.x

Tompkins, E. L. 2005. Planning for climate change in small islands: insights from national hurricane preparedness in the Cayman Islands. Global Environmental Change 15:139-149. http://dx.doi.org/10.1016/j.gloenvcha.2004.11.002
Tompkins, E. L., and W. N. Adger. 2005. Defining response capacity to enhance climate change policy. Environmental Science and Policy 8:562-571. http://dx.doi.org/10.1016/j. envsci.2005.06.012

Tompkins, E. L., M. C. Lemos, and E. Boyd. 2008. A less disastrous disaster: managing response to climate-driven hazards in the Cayman Islands and NE Brazil. Global Environmental Change 18:736-745. http://dx.doi.org/10.1016/ j.gloenvcha.2008.07.010

Tyler, N. J. C., J. M. Turi, M. A. Sundset, K. S. Bull, M. N. Sara, E. Reinert, N. Oskal, C. Nellemann, J. J. McCarthy, S. D. Mathiesen, M. L. Martello, O. H. Magga, G. K. Hovelsrud, I. Hanssen-Bauer, N. I. Eira, I. M. G. Eira, and R. W. Corell. 2007. Saami reindeer pastoralism under climate change: applying a generalized framework for vulnerability studies to a sub-arctic social-ecological system. Global Environmental Change 17:191-206.

Underdal, A. 2010. Complexity and challenges of long-term environmental governance. Global Environmental Change 20:386-393. http://dx.doi.org/10.1016/j.gloenvcha.2010.02.005

van Asselt, M. B. A. 2010. Uit zicht: toekomstverkennen met beleid. Amsterdam University Press, Amsterdam, Netherlands.

van Asselt, M. B. A., J. Mesman, and S. A. van't Klooster. 2007. Dealing with prognostic uncertainty. Futures 39:669-684. http://dx.doi.org/10.1016/j.futures.2006.11.011

van der Steen. 2009. Een sterk verhaal. Een analyse van het discours over vergrijzing. Lemma, The Hague, Netherlands.

Vink, M. J., D. Boezeman, A. Dewulf, and C. J. A. M. Termeer. 2013. Changing climate, changing frames: Dutch water policy frame developments in the context of a rise and fall of attention to climate change. Environmental Science and Policy 30:90-101. http://dx.doi.org/10.1016/j.envsci.2012.10.010

Visser, J., and A. Hemerijck. 1997. A Dutch miracle: job growth, welfare reform and corporatism in the Netherlands. Amsterdam University Press, Amsterdam, Netherlands. http:// dx.doi.org/10.5117/9789053562710

Wells, H. G. 1902. The discovery of the future. Nature 65:326-330.

Wolf, J. 2011. Climate change adaptation as a social process. Pages 21-32 in J. D. Ford and L. Berrang-Ford, editors. Climate change adaptation in developed nations: from theory to practice. Springer, New York, New York, USA. http://dx. doi.org/10.1007/978-94-007-0567-8 2 


\section{Appendix 1}

\section{Search queries on knowledge and power conceptualizations in CCAG literature:}

1. General Climate adaptation governance:

TITLE-ABS-KEY(("climat* change" OR "global warming") AND (adapt*) AND (govern*)) total 1132; H-factor 40

2. Climate adaptation governance + unorganized knowledge:

TITLE-ABS-KEY(("climat* change" OR "global warming") AND (adapt*) AND (govern*) AND (learn* OR puzzl* $^{*}$ OR idea* OR ((knowledge OR experience) AND shar* $\left.{ }^{\star}\right)$ OR framing OR frame OR frames OR deliberat*)) total 181 ; H-factor 21

3. Climate adaptation governance + organized knowledge:

TITLE-ABS-KEY(("climat* change" OR "global warming") AND (adapt*) AND (govern*) AND (model* OR techn* OR scenar*)) total 438; H-factor 30

4. Climate adaptation governance + unorganized power:

TITLE-ABS-KEY(("climat* change" OR "global warming") AND (adapt*) AND (govern*) AND (negot* OR striv* OR *powering* OR ("power* AND play*) OR ("power relation"") OR ("power* AND dynamic*) OR ("power* AND process $\left.\left.{ }^{\star}\right)\right)$ ) total $70 ; \mathrm{H}$-factor 9

5. General Climate adaptation governance + organized power:

TITLE-ABS-KEY(("climat* change" OR "global warming") AND (adapt*) AND (govern*) AND (institution* OR regulat* OR law* OR legal $\left.^{\star}\right)$ ) total 436 ; $\mathrm{H}$-factor 28

6. Climate adaptation governance + no knowledge:

TITLE-ABS-KEY(("climat* change" OR "global warming") AND (adapt*) AND (govern*) AND NOT (learn* OR

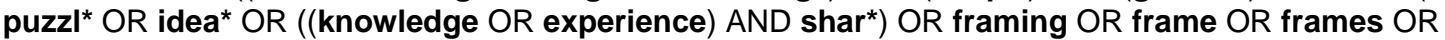
deliberat $^{\star}$ ) AND NOT (model* OR techn* OR scenar*)) total 608 ; $\mathrm{H}$-factor 28

7. Climate adaptation governance + no power:

TITLE-ABS-KEY(("climat* change" OR "global warming") AND (adapt $\left.{ }^{\star}\right)$ AND (govern*) AND NOT (negot* OR striv* OR *powering* OR ("power* AND play*) OR ("power relation*") OR ("power* AND dynamic*) OR (" power* AND process $\left.^{\star}\right)$ ) AND NOT (institution* OR regulat* OR law* OR legal*)) total 684; $\mathrm{H}$-factor 33

\section{Combined search queries on knowledge and power conceptualisations in CCAG literature}

1. organized knowledge + organized power

TITLE-ABS-KEY(("climat* change" OR "global warming") AND (adapt*) AND (govern*) AND (model* OR techn* OR scenar*) AND (institution* OR regulat* OR law* OR legal*)) total 152; H-factor 18

2. Unorganized knowledge + organized power

TITLE-ABS-KEY(("climat* change" OR "global warming") AND (adapt*) AND (govern*) AND (institution* OR regulat $^{\star}$ OR law* OR legal $\left.{ }^{\star}\right)$ AND (learn* OR puzzl* OR idea* OR ((knowledge OR experience) AND shar $\left.{ }^{\star}\right)$ OR framing OR frame OR frames OR deliberat $\left.{ }^{\star}\right)$ ) total $91 ; \mathrm{H}$-factor 14

3. $\quad$ organized knowledge + unorganized power

TITLE-ABS-KEY(("climat* change" OR "global warming") AND (adapt*) AND (govern*) AND (model* OR techn* OR scenar*) AND (negot* OR striv* OR *powering* OR ("power* AND play*) OR ("power relation" OR ( ${ }^{*}$ power ${ }^{\star}$ AND dynamic $\left.{ }^{*}\right)$ OR $\left({ }^{*}\right.$ power $^{\star}$ AND process $\left.\left.\left.{ }^{*}\right)\right)\right)$ total 26 ; $\mathrm{H}$-factor 5 
4. Unorganized knowledge + unorganized power

TITLE-ABS-KEY(("climat ${ }^{\star}$ change" OR "global warming") AND (adapt*) AND (govern*) AND (learn* OR puzzl* $^{\star}$ OR idea* OR ((knowledge OR experience) AND shar*) OR framing OR frame OR frames OR

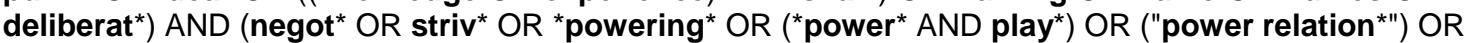
$\left({ }^{*}\right.$ power $^{*}$ AND dynamic $\left.{ }^{*}\right)$ OR ("${ }^{*}$ power $^{*}$ AND process $\left.\left.{ }^{*}\right)\right)$ ) total 16 ; $\mathrm{H}$-factor 3

\section{Combined search queries on either knowledge or power conceptualisations in CCAG literature}

\section{Unorganized knowledge + no power}

TITLE-ABS-KEY(("climat ${ }^{\star}$ change" OR "global warming") AND (adapt $\left.{ }^{\star}\right)$ AND (govern $\left.{ }^{\star}\right)$ AND (learn* OR puzzl $^{\star}$ OR idea* OR ((knowledge OR experience) AND shar $\left.{ }^{\star}\right)$ OR framing OR frame OR frames OR deliberat*) AND NOT (negot* OR striv* OR *powering* OR ("power* AND play*) OR ("power relation*") OR

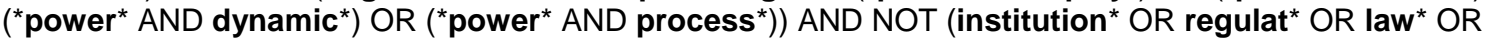
legal $\left.{ }^{\star}\right)$ ) total 85 ; $\mathrm{H}$-factor 13

\section{Organized knowledge + no power}

TITLE-ABS-KEY(("climat* change" OR "global warming") AND (adapt*) AND (govern*) AND (model* OR techn* OR scenar*) AND NOT (negot* OR striv* OR *powering* OR ("power* AND play*) OR ("power

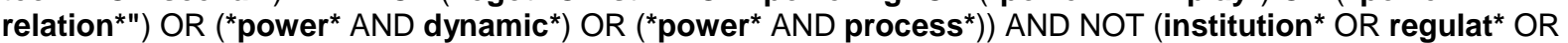

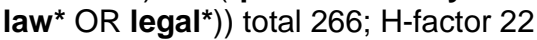

7. Unorganized power + no knowledge

TITLE-ABS-KEY(("climat* change" OR "global warming") AND (adapt*) AND (govern*) AND (negot* OR striv* OR *powering* OR ("power* AND play*) OR ("power relation*") OR (*power* AND dynamic*) OR (*power* AND process*)) AND NOT (learn* OR puzzl* OR idea* OR ((knowledge OR experience) AND shar*) OR framing OR frame OR frames OR deliberat ${ }^{\star}$ ) AND NOT (model ${ }^{\star}$ OR techn* OR scenar*)) total 35 ; $\mathrm{H}$-factor 8

8. Organized power + no knowledge

TITLE-ABS-KEY(("climat* change" OR "global warming") AND (adapt*) AND (govern*) AND (institution* OR

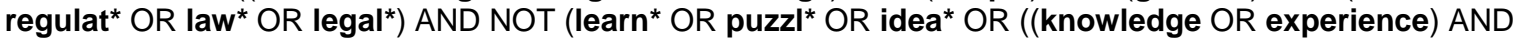
shar $^{\star}$ ) OR framing OR frame OR frames OR deliberat ${ }^{\star}$ ) AND NOT (model* OR techn* OR scenar*)) total 221; $\mathrm{H}$-factor 15

9. No power + no knowledge

TITLE-ABS-KEY(("climat* change" OR "global warming") AND (adapt*) AND (govern*) AND NOT (negot* OR striv* OR *powering* OR ("power* AND play*) OR ("power relation*") OR ("power* AND dynamic*) OR (*power* AND process*)) AND NOT (institution* OR regulat* OR law* OR legal ${ }^{\star}$ ) AND NOT (learn* OR puzzl* OR idea* OR ((knowledge OR experience) AND shar*) OR framing OR frame OR frames OR deliberat $\left.{ }^{\star}\right)$ AND NOT (model* OR techn* OR scenar $\left.{ }^{\star}\right)$ ) total 356; H-factor 25 


\section{Appendix 2.}

Table A2.1

\begin{tabular}{|c|c|c|c|c|}
\hline \multicolumn{5}{|c|}{ Organised knowledge and organised power } \\
\hline $\mathrm{Nr}$. & Author(s) & $\begin{array}{l}\text { Level of } \\
\text { governance }\end{array}$ & $\begin{array}{l}\text { Empirical or } \\
\text { theoretical focus }\end{array}$ & Knowledge and power interplay conceptualized \\
\hline 1 & (Mills 2005) & National & Empirical & $\begin{array}{l}\text { Organized power (regulators and regulation) and organized knowledge } \\
\text { (damage models) in CCAG are diagnosed and conceptualized as static } \\
\text { but problematic in relation to a changing climate. Both are approached } \\
\text { as separate dimensions in CCAG which in the specific case interplay in a } \\
\text { non-preferable way with a changing climate. Models and regulation } \\
\text { should change. }\end{array}$ \\
\hline 2 & $\begin{array}{l}\text { (Challinor et al. } \\
2007 \text { ) }\end{array}$ & National & Theoretical & $\begin{array}{l}\text { Organized power (institutions) and organized knowledge (climate } \\
\text { models, crop yield models) are diagnosed and show an un-preferable } \\
\text { picture in combination with a changing climate. Institutions should } \\
\text { change to overcome this problematic picture. }\end{array}$ \\
\hline 3 & (Easterling 1996) & National & Theoretical & $\begin{array}{l}\text { Organized power (political institutions) together with organized } \\
\text { knowledge (models \& techniques) are parameters in a full system } \\
\text { analyses to predict non-preferable consequences of a changing climate. } \\
\text { No conceptual integration is made between institutions, models or } \\
\text { techniques. }\end{array}$ \\
\hline 4 & $\begin{array}{l}\text { (Tompkins and } \\
\text { Adger 2005) }\end{array}$ & National & Theoretical & $\begin{array}{l}\text { Organized power (institutions) and organized knowledge (techniques) } \\
\text { are conceptualized as central to CCAG, together with social behaviour } \\
\text { and learning. Hence, the article goes beyond organized power and } \\
\text { knowledge alone and includes unorganized power too in its } \\
\text { conceptualization of CCAG. In addition the paper conceptualizes the } \\
\text { relation between institutions and social behaviour by explaining the role } \\
\text { of institutions on behaviour and techniques as response mechanisms to } \\
\text { CC. }\end{array}$ \\
\hline 5 & $\begin{array}{l}\text { (Belliveau et al. } \\
2006 \text { ) }\end{array}$ & Local / National & Empirical & $\begin{array}{l}\text { Organized power (institutions) and organized knowledge (agricultural } \\
\text { techniques) are assessed for influence on farmers sensitivity for climate } \\
\text { change. The relation between institutions and techniques is not } \\
\text { conceptualized. }\end{array}$ \\
\hline 6 & (Tyler et al. 2007) & Local / National & Empirical & $\begin{array}{l}\text { Organized power (institutions and legal constrains) and organized } \\
\text { knowledge (models and knowledge systems) are assessed for their } \\
\text { influence on herders vulnerability for climate change impacts. No } \\
\text { conceptualization is made of the relation between knowledge systems } \\
\text { and legal / institutional systems. }\end{array}$ \\
\hline 7 & $\begin{array}{l}\text { (Biesbroek et al. } \\
2010 \text { ) }\end{array}$ & National & Empirical & $\begin{array}{l}\text { Among other governance issues organized power (institutions and } \\
\text { regulation) and organized knowledge (techniques) are assessed and } \\
\text { compared among different European nation states. A possible interplay } \\
\text { between institutions and techniques is not conceptualized. }\end{array}$ \\
\hline 8 & $\begin{array}{l}\text { (Allman et al. } \\
\text { 2004) }\end{array}$ & Local & Empirical & $\begin{array}{l}\text { Among a wide range of aspects organized knowledge (regulation) and } \\
\text { organized knowledge (techniques) are assessed in explaining the success } \\
\text { of local CCAG systems. The article also covers unorganized forms of } \\
\text { knowledge (learning) but does not conceptualize a possible interplay. }\end{array}$ \\
\hline 9 & $\begin{array}{l}\text { (Sanders and } \\
\text { Phillipson 2003) }\end{array}$ & National & Theoretical & $\begin{array}{l}\text { Organized power (insurance and building regulation \& regulators) and } \\
\text { organized knowledge (knowledge systems on climate, techniques, like } \\
\text { buildings) are assessed in view of a changing climate. There is a } \\
\text { dependant relation conceptualized between both. Knowledge systems } \\
\text { consisting of decades of climate data determine regulation and will only } \\
\text { very gradually change. }\end{array}$ \\
\hline 10 & (Ford et al. 2010) & National & Empirical & $\begin{array}{l}\text { Among a variety of CCAG aspects organized power (institutions) and } \\
\text { organized knowledge (technology) are assessed in their role in health } \\
\text { vulnerability of aboriginals in context of a changing climate. Both } \\
\text { concepts are conceptually linked with unorganized forms knowledge } \\
\text { (learning) by assessing their capacity to adapt. }\end{array}$ \\
\hline
\end{tabular}

Table A2.2

\begin{tabular}{|l|l|l|l|l|}
\hline \multicolumn{3}{|l|}{ Unorganized knowledge and organized power } \\
\hline Nr. & Author(s) & $\begin{array}{l}\text { Level of CCA } \\
\text { governance }\end{array}$ & $\begin{array}{l}\text { Empirical or } \\
\text { theoretical focus } \\
\text { on CCAG }\end{array}$ & Knowledge and power interplay conceptualized in CCAG \\
\hline 1 & (Pahl-Wostl & $\begin{array}{l}\text { Not explicitly } \\
\text { addressed. } \\
\text { Implicitly the } \\
\text { national or local } \\
\text { level of } \\
\text { governance is } \\
\text { mentioned as the } \\
\text { level of analyses. }\end{array}$ & $\begin{array}{l}\text { Theoretical with } \\
\text { empirical } \\
\text { illustrations }\end{array}$ & $\begin{array}{l}\text { Organized power (institutions) is related to unorganized knowledge } \\
\text { (learning) through single, double and triple loop learning. CCAG } \\
\text { institutions exist of agents which may learn from each other in networks } \\
\text { of various complexity, the complexer the network the better the } \\
\text { institutional learning. }\end{array}$ \\
\hline
\end{tabular}




\begin{tabular}{|c|c|c|c|c|}
\hline 2 & $\begin{array}{l}\text { (Pelling et al. } \\
\text { 2008) }\end{array}$ & $\begin{array}{l}\text { Not explicitly } \\
\text { addressed, cases } \\
\text { are at a national } \\
\text { level }\end{array}$ & $\begin{array}{l}\text { Theoretical } \\
\text { underpinned by } \\
\text { a single case } \\
\text { study }\end{array}$ & $\begin{array}{l}\text { Organized power in form of CCAG organizations are dealing with } \\
\text { unorganized knowledge (learning) through individual learning and } \\
\text { collective learning at different levels. When learning takes place at a } \\
\text { discrete subgroup level, mutual institutions will change and ultimately } \\
\text { the organization will learn as a whole and change accordingly. }\end{array}$ \\
\hline 3 & $\begin{array}{l}\text { (Tompkins and } \\
\text { Adger 2005) }\end{array}$ & All levels & Theoretical & $\begin{array}{l}\text { Organized power in form of institutions in CCAG is mentioned as } \\
\text { structural to acceptability, resource availability and social change. In this } \\
\text { context social learning is mentioned as important for response capacity } \\
\text { to climate change. }\end{array}$ \\
\hline 4 & $\begin{array}{l}\text { (Nelson et al. } \\
2008)\end{array}$ & National & Empirical & $\begin{array}{l}\text { Organized power in form of institutions and state organizations } \\
\text { coproducing CCAG knowledge in cooperation with local communities is } \\
\text { conceptualized as adaptive governance. }\end{array}$ \\
\hline 5 & $\begin{array}{l}\text { (Gupta et al. } \\
\text { 2010) }\end{array}$ & Local / National & Theoretical & $\begin{array}{l}\text { A model is developed for assessing forms of organized power (e.g. } \\
\text { institutions) on their capacity to adapt to changing circumstances like } \\
\text { climate change. Learning is considered one of the central capacities for } \\
\text { adaptive capacity. }\end{array}$ \\
\hline 6 & (Tompkins 2005) & National & Empirical & $\begin{array}{l}\text { Organized forms of power (e.g.) national institutions are examined to } \\
\text { their adaptive capacity. The willingness to learn, and learning-based } \\
\text { institutions are conceptualized as institutional resilience. In addition the } \\
\text { author links to more unorganized forms of power by stressing the need } \\
\text { for prioritisation. }\end{array}$ \\
\hline 7 & $\begin{array}{l}\text { (Shackley and } \\
\text { Deanwood 2002) }\end{array}$ & Local & Empirical & $\begin{array}{l}\text { Taking an agent centred approach in which organized forms of power } \\
\text { (institutions) are conceptualized as perceptions or 'frame of reference' } \\
\text { The fit of the climate change framing with the existing institutional or } \\
\text { 'system' frame of reference and other existing frames of reference like } \\
\text { 'processes' and 'response mechanisms' determine the responsiveness of } \\
\text { governance to climate change adaptation. }\end{array}$ \\
\hline 8 & $\begin{array}{l}\text { (Dovers and Hezri } \\
\text { 2010) }\end{array}$ & Not relevant & $\begin{array}{l}\text { Review of } \\
\text { literature }\end{array}$ & $\begin{array}{l}\text { Organized forms of power in CCAG are conceptualized as institutions } \\
\text { and regulation after a common understanding in CCAG literature. This is } \\
\text { done in the same way for unorganized forms of knowledge like learning } \\
\text { and the sharing of knowledge. The lack of integration of both aspects in } \\
\text { CCAG literature is mentioned as a challenge for CCAG science. } \\
\text { Studying the concept of policy processes is mentioned as a possible } \\
\text { integration of both concepts. }\end{array}$ \\
\hline 9 & $\begin{array}{l}\text { (Dougill et al. } \\
2010 \text { ) }\end{array}$ & Local & Empirical & $\begin{array}{l}\text { Organized forms of power (institutions) are mentioned together with } \\
\text { unorganized forms of knowledge (learning) as important. A conceptual } \\
\text { link between both dimensions is not specified, although institutions are } \\
\text { mentioned as a possible enforcement for learning. }\end{array}$ \\
\hline 10 & $\begin{array}{l}\text { (Tompkins et al. } \\
\text { 2008) }\end{array}$ & National & Empirical & $\begin{array}{l}\text { Organized forms of power (e.g. institutions) are conceptualized next to } \\
\text { other forms of power (e.g. support by local population) and unorganized } \\
\text { forms of knowledge (learning and sharing of knowledge) as important } \\
\text { for response to climate change impacts. The interplay of both is } \\
\text { conceptualized as 'learning-based institutions' but is not elaborated. }\end{array}$ \\
\hline
\end{tabular}

Table A2.3

\begin{tabular}{|c|c|c|c|c|}
\hline \multicolumn{5}{|c|}{ Organized knowledge and unorganized power } \\
\hline $\mathrm{Nr}$. & Author(s) & $\begin{array}{l}\text { Level of } \\
\text { governance }\end{array}$ & $\begin{array}{l}\text { Empirical or } \\
\text { theoretical focus }\end{array}$ & Knowledge and power interplay conceptualized \\
\hline 1 & (Underdal 2010) & $\begin{array}{l}\text { Global / national } \\
\text { / local }\end{array}$ & Theoretical & $\begin{array}{l}\text { Organized knowledge and unorganized power are conceptualized as } \\
\text { different governance models (centralised depending on concentrated } \\
\text { negotiational power, or decentralised depending on decentralised, } \\
\text { adapted knowledge systems), each functioning best in specific } \\
\text { conditions. }\end{array}$ \\
\hline 2 & $\begin{array}{l}\text { (McGee and } \\
\text { Taplin 2009) }\end{array}$ & Global & Empirical & $\begin{array}{l}\text { Organized knowledge (models on how to combat climate change) and } \\
\text { unorganized power (international negotiations) are conceptualized as } \\
\text { intertwined. Through discursive analysis the authors conclude that the } \\
\text { model underpinning the APP international agreement on adaptation and } \\
\text { other measures combating climate change has impacts on international } \\
\text { negotiations on the Kyoto protocol. }\end{array}$ \\
\hline 3 & $\begin{array}{l}\text { (Roncoli et al. } \\
2009 \text { ) }\end{array}$ & National & Empirical & $\begin{array}{l}\text { Organized knowledge (modelling tools) and unorganized power } \\
\text { (negotiation) are conceptualized rather separately. The interplay emerges } \\
\text { where the authors describe how modelling tools give handles for } \\
\text { negotiation }\end{array}$ \\
\hline 4 & $\begin{array}{l}\text { (Carey et al. } \\
\text { 2012) }\end{array}$ & National & Empirical & $\begin{array}{l}\text { Organized knowledge (climate models and technology) and unorganized } \\
\text { power (negotiations) are conceptualized as 'mutually constitutive', } \\
\text { where climate models and technologies shape power relations yielding } \\
\text { the concept 'politics of technologies' }\end{array}$ \\
\hline 5 & $\begin{array}{l}\text { (Mahony and } \\
\text { Hulme 2012) }\end{array}$ & Global / National & Empirical & $\begin{array}{l}\text { Unorganized knowledge (deliberation and re-framing) in relation to the } \\
\text { development of organized knowledge (climate models and expertise) is } \\
\text { conceptualized as influencing unorganized power (negotiations). } \\
\text { Knowledge hegemony at the IPCC therefore influences the power of the } \\
\text { global south to adapt to CC. This leads to the possibility of taking a } \\
\text { normative stance in the production of organized knowledge. }\end{array}$ \\
\hline 6 & (Feldman 2012) & National /local & Theoretical & Both unorganized (sharing of experiences) and organized knowledge \\
\hline
\end{tabular}




\begin{tabular}{|l|l|l|}
\hline & & $\begin{array}{l}\text { (models \& technology) is hindered in its effect on climate impacts due to } \\
\text { both unorganized (negotiations) and organized power (institutions). The } \\
\text { relation between both dimensions is conceptualized in 'boundary work' } \\
\text { which might be less or more effective due to different forms of } \\
\text { unorganized and organized power. }\end{array}$ \\
\hline
\end{tabular}

Table A2.4

\begin{tabular}{|c|c|c|c|c|}
\hline \multicolumn{5}{|c|}{ Unorganized knowledge and unorganized power } \\
\hline $\mathrm{Nr}$. & Author(s) & $\begin{array}{l}\text { Level of } \\
\text { governance }\end{array}$ & $\begin{array}{l}\text { Empirical or } \\
\text { theoretical focus }\end{array}$ & Knowledge and power interplay conceptualized \\
\hline 1 & $\begin{array}{l}\text { (Brown et al. } \\
2007 \text { ) }\end{array}$ & Global & $\begin{array}{l}\text { Theoretical, } \\
\text { empirically } \\
\text { illustrated }\end{array}$ & $\begin{array}{l}\text { Unorganized knowledge (frames) is conceptualized in relation to } \\
\text { unorganized power (negotiations). If climate adaptation is internationally } \\
\text { framed as a security issue, this will change negotiational power for } \\
\text { effected regions like Africa in relation to the international community. }\end{array}$ \\
\hline 2 & $\begin{array}{l}\text { (Roncoli et al. } \\
2009 \text { ) }\end{array}$ & National & Empirical & $\begin{array}{l}\text { Unorganized knowledge (frames) is conceptualized in relation to the } \\
\text { deliberative use of organized knowledge (models) in unorganized power } \\
\text { (negotiations). }\end{array}$ \\
\hline 3 & $\begin{array}{l}\text { (Mahony and } \\
\text { Hulme 2012) }\end{array}$ & Global / National & Empirical & $\begin{array}{l}\text { Unorganized knowledge (deliberation and re-framing) in relation to the } \\
\text { development of organized knowledge (climate models and expertise) is } \\
\text { conceptualized as influencing unorganized power (negotiations). } \\
\text { Knowledge hegemony at the IPCC therefore influences the power of the } \\
\text { global south to adapt to CC. This leads to the possibility of taking a } \\
\text { normative stance in the production of organized knowledge. }\end{array}$ \\
\hline 4 & (Vink et al. 2013) & National & Empirical & $\begin{array}{l}\text { Unorganized knowledge (frames) is conceptualized in relation to } \\
\text { employed knowledge systems and the possible negotiational strategies } \\
\text { this framing enables }\end{array}$ \\
\hline 5 & (Feldman 2012) & National / Local & Theoretical & $\begin{array}{l}\text { Both unorganized (sharing of experiences) and organized knowledge } \\
\text { (models \& technology) is hindered in its effect on climate impacts due to } \\
\text { both unorganized (negotiations) and organized power (institutions). The } \\
\text { relation between both dimensions is conceptualized in 'boundary work' } \\
\text { and 'knowledge networks' which might be less or more effective due to } \\
\text { different forms of unorganized and organized power. }\end{array}$ \\
\hline 6 & $\begin{array}{l}\text { (Herrfahrdt-Pähle } \\
\text { and Pahl-Wostl } \\
\text { 2012) }\end{array}$ & National & Empirical & $\begin{array}{l}\text { Unorganized power (negotiation) is conceptualized in relation with } \\
\text { unorganized knowledge (learning) via the concept of 'triple loop } \\
\text { learning'. This type of learning is yielding changing values and } \\
\text { ultimately changing institutions. Via changed institutions this learning is } \\
\text { related to sustained change in the characteristics of political negotiations } \\
\text { over long term issues like CCAG. }\end{array}$ \\
\hline 7 & $\begin{array}{l}\text { (Manuel- } \\
\text { Navarrete 2010) }\end{array}$ & National & Theoretical & $\begin{array}{l}\text { Unorganized power (negotiational power relations) are conceptualized } \\
\text { as closely related to unorganized knowledge (ideas and theories) } \\
\text { currently leading to asymmetric global power relations hindering climate } \\
\text { adaptation. }\end{array}$ \\
\hline 8 & (Rojas et al. 2009) & National & Empirical & $\begin{array}{l}\text { Unorganized knowledge (learning) is conceptualized as influencing } \\
\text { unorganized power (negotiation) by proper multi-stakeholder } \\
\text { consultation. }\end{array}$ \\
\hline
\end{tabular}

